\title{
LORONG WAKTU REVOLUSI SAINTIFIK PADA ERA EKSPONENSIAL
}

\author{
Muhammad Syaipul Hayat ${ }^{1^{\star}}$, Sutarno ${ }^{2}$, dan Erwin ${ }^{3}$ \\ ${ }^{1}$ Program Studi Pendidikan Biologi FPMIPATI Universitas PGRI Semarang \\ ${ }^{2}$ Program Studi Pendidikan Fisika FKIP Universitas Bengkulu \\ ${ }^{3}$ Program Studi Pendidikan Fisika STKIP Nurul Huda \\ *E-mail: m.syaipulhayat@upgris.ac.id
}

\begin{abstract}
Abstrak
Sejak awal perkembangannya pada abad 17 perkembangan sains dari masa ke masa terus mengalami kemajuan yang pesat. Bahkan perkembangan yang terjadi merubah paradigma berpikir para filsuf sains secara fundamental, pada akhirnya terjadi revolusi saintifik. Perkembangan sains terus terjadi hingga saat ini, bahkan kemajuannya bergerak semakin cepat, sehingga era saat ini disebut sebagai era eksponensial. Indikator dari revolusi saintifik di era eksponensial adalah banyaknya teknologi yang ditemukan oleh para ilmuwan sains modern yang sangat mutakhir dalam berbagai sektor kehidupan masyarakat. Beberapa contoh diantaranya adalah kemampuan teknologi dalam menjelajahi dunia maya, yang memudahkan masyarakat dalam komunikasi jarak jauh, berinteraksi, memperoleh informasi, layanan kesehatan, artificial intelligent, dan sebagainya. Dampak yang paling dirasakan oleh masyarakat dunia akibat dari revolusi sains di era eksponensial adalah dalam bidang bioteknologi. Para ilmuwan telah banyak menghasilkan penemuan-penemuan yang mencengangkan, yaitu diciptakannya sistem biologis yang baru, baik pada tingkat molekul, sel, atau organisme baru melalui metode biologi sintesis (syinthetic biology). Teknologi ini akan menjadi salah satu alternatif untuk produksi pangan yang murah, energi terbarukan, perakitan varietas tanaman tahan cekaman biotik dan abiotik, dihasilkannya vaksin, organisme baru, dan lain-lain. Artikel ini akan membahas pandangan filsafat terhadap revolusi saintifik pada era eksponensial.
\end{abstract}

Kata kunci: Revolusi saintifik, filsafat sains, era eksponensial, biologi sintetis.

\section{PENDAHULUAN}

Tatanan kehidupan masyarakat di dunia saat ini sudah dirasakan banyak mengalami pergeseran, dan bahkan perubahan yang bersifat fundamental pada tataran filsafat, arah serta tujuannya. Pergeseran tersebut disebabkan karena perkembangan sains yang begitu cepat dari waktu ke waktu. Bahkan, kecepatan perkembangan sains tersebut sulit untuk dicegah, dihindari bahkan dihentikan, karena itu merupakan sesuatu yang mustahil untuk dilakukan. Tjandrawinata (2016) mengemukakan, terdapat perbedaan mendasar dalam skala, ruang lingkup, dan kompleksitasnya, transformasi yang sedang terjadi dengan apa yang telah dialami manusia sebelumnya. Kita belum tahu persis apa yang akan terjadi di masa depan, tetapi ada satu hal yang jelas bahwa dunia harus merespon terhadap perubahan tersebut secara integratif dan komprehensif dengan melibatkan seluruh pemangku kepentingan politik global, mulai dari sektor publik dan swasta, sampai akademisi, dan tentunya masyarakat sipil.

Perkembangan sains yang sangat cepat sudah dapat dirasakan bagaikan lorong waktu. Ungkapan tersebut tidaklah berlebihan, mengingat saat ini segala akses informasi sangat mudah untuk diperoleh dalam berbagai sektor kehidupan manusia. Sebagai contoh, kita dapat mengetahui informasi, aktivitas seseorang, bahkan berinteraksi melalui dunia maya, yang pada era sebelumnya hal tersebut sangat mustahil untuk dilakukan. Contoh lain, kita juga dapat melakukan diagnosa kesehatan menggunakan alat yang supercanggih seperti MRI, USG, X-ray, dan sebagainya. Lebih dari itu, saat ini sedang dikembangkan telemedicine, yaitu suatu teknologi pemantauan dan pengobatan pasien dari jarak jauh melalui sensor yang tersambung ke internet (Tjandrawinata, 2016). Dengan demikian kita dapat mengetahui kondisi yang sedang dirasakan dan dapat melakukan penanganannya secara mutakhir tanpa harus berkunjung ke Rumah Sakit, karena sudah cukup melakukan chek-up medis 
secara nyaman di rumah masing-masing.

Perubahan besar yang terjadi dalam dunia sains disebut dengan revolusi saintifik atau revolusi sains, karena perkembangan yang terjadi tidak linear melainkan melalui proses perubahan fundamental, teori baru tidak kompatibel dengan teori lama (Kuhn, 1962). Revolusi sains memberikan dampak pada berbagai bidang, terutama bidang industri. Oleh karenanya, revolusi sains selalu diikuti dengan terjadinya revolusi industri. Berdasarkan sejarah, sains berkembang secara pesat sejak kelahirannya pada abad-abad pertengahan hingga saat ini (Firman, 2016). Hal tersebut sejalan dengan proses terjadinya Revolusi Industri, mulai dari revolusi industri pertama pada tahun 1784 yang memperkaya air dan uap untuk mekanisasi sistem produksi. Revolusi Industri kedua yang dimulai tahun 1870 menggunakan daya listrik untuk melangsungkan produksi masal. Revolusi Industri ketiga yang terjadi sejak tahun 1969 menggunakan kekuatan elektronik dan teknologi informasi untuk otomatisasi proses produksi (Tjandrawinata, 2016). Dalam waktu dekat, kita harus siap dengan terjadinya revolusi Industri keempat yang disebut sebagai revolusi eksponensial, yaitu revolusi sains yang berkembang dengan kecepatan sangat cepat.

Revolusi industri keempat ditandai dengan bersatunya beberapa teknologi dari tiga bidang independen, yaitu fisika, digital dan biologi. Bersatunya bidang ilmu tersebut memberikan "daya ledak" yang sangat besar terhadap kehidupan manusia, karena skala tantangannya tidak dapat dianggap remeh terutama dalam bidang bioteknologi kesehatan. Hal tersebut menurut Tjandrawinata (2016) dibuktikan dengan penemuan terbaru dalam dunia medis, yaitu CRISPR (clustered regularly interspaced short palindromic repeat), sebuah teknologi yang berkembang sangat cepat untuk mengedit genom secara biologi sintetis, skrining genom fungsional, modulasi transkripsi, dan terapi gen. Teknologi tersebut adalah temuan baru yang harus menjawab secara gamblang pertanyaan moral dan etika yang muncul sebagai respon terhadap penelitian mutakhir dalam bidang bioteknologi yang akan memungkinkan perpanjangan masa hidup manusia, "merancang bayi", maupun ekstraksi ingatan manusia.

Berdasarkan pendahuluan yang telah dipaparkan, rumusan masalah dalam penulisan makalah ini adalah:

1. Bagaimanakah sejarah terjadinya revolusi saintifik hingga sampai pada era eksponensial?

2. Apakah pemikiran utama revolusi saintifik pada era eksponensial?

3. Bagaimanakah pandangan filsafat terhadap revolusi saintifik pada era eksponensial?

4. Bagaimanakah persepsi masyarakat dalam menyikapi revolusi saintifik pada era eksponensial?

\section{HASIL DAN PEMBAHASAN}

\section{Sejarah Terjadinya Revolusi Saintifik}

Dari masa ke masa sains terus mengalami perkembangan, bahkan perkembangan yang terjadi mengalami perubahan yang sangat fundamental dari kondisi sebelumnya. Hal tersebut dikarenakan para saintis berpikir maju dan selalu berusaha memecahkan permasalahan-permasalahan sains yang dihadapi oleh masyarakat dengan melakukan berbagai penemuan. Banyak kemajuan sains didasari oleh perubahan pemikiran para saintis secara fundamental, yang melihat fenomena masyarakat saat itu memanfaatkan sains secara praktis. Perubahan pemikiran tersebut, oleh Kuhn (1962) disebut sebagai paradigma (paradigm) keilmuan. Pergeseran paradigma menurut Kuhn (1962) adalah istilah untuk menggambarkan terjadinya pemikiran kreatif pikiran manusia dalam dimensi filsafat. Pergeseran paradigma merupakan letupan ide yang memicu lahirnya ide-ide yang lain, yang terjadi secara terusmenerus baik pada orang yang sama maupun orang yang berbeda. Reaksi berantai ini akhirnya menjadi kekuatan yang bisa merubah wajah dan tatanan dunia serta peradaban manusia ke arah suatu kemajuan.

Paradigma keilmuan erat kaitannya dengan sains normal, berarti riset yang didasari oleh satu atau lebih pencapaian ilmiah yang lalu, pencapaian yang oleh masyarakat ilmiah tertentu pada suatu ketika dinyatakan sebagai pemberi pondasi pada praktek selanjutnya. Kuhn (1962) di dalam bukunya mengemukakan bahwa sains yang normal adalah kegiatan pemecahan masalah yang sangat 
kumulatif, benar-benar berhasil dalam tujuannya, pengetahuan secara tetap ruang lingkup dan presisi pengetahuan sains. Sains yang normal tidak ditujukan kepada kebaruan-kebaruan fakta atau teori, dan jika berhasil tidak menemukan hal tersebut. Firman (2016) memperkuat bahwa akumulasi pengetahuan dalam sains normal mengokohkan paradigma yang didukung, sampai diperoleh fakta-fakta yang tidak berseuaian dengan teori-teori dominan yang diyakini banyak ilmuan, atau disebut anomali.

Berbagai fenomena (anomali) bisa dijumpai oleh para saintis selama menjalankan riset dalam sains normal. Jika anomali semakin banyak, maka akan timbul krisis dan paradigma mulai dipertanyakan. Penemuan baru diawali dengan kesadaran akan anomali, yakni pengakuan bahwa alam dengan suatu cara telah melanggar pengharapan yang didorong oleh paradigma yang menguasai sains normal. Kemudian ia berlanjut dengan eksplorasi yang sedikit banyak diperluas ke wilayah anomali dan hanya berakhir bila teori atau paradigma itu telah disesuaikan sehingga yang menyimpang menjadi sesuai dengan yang diharapkan. Sehingga, dalam penemuan baru harus ada penyesuaian antara fakta dengan teori yang baru. Hal tersebut selanjutnya dinamakan revolusi sains, oleh Kuhn (1962) dikatakan sebagai episode perkembangan non-kumulatif, dimana paradigma lama diganti sebagian atau seluruhnya oleh paradigma baru yang bertentangan. Transformasi-transformasi paradigma yang berurutan dari paradigma yang satu ke paradigma yang lainnya melalui revolusi, adalah pola perkembangan yang biasa dari sains yang telah matang.

Sejarah revolusi sains sejalan dengan terjadinya revolusi industri. Faktor yang melatarbelakangi terjadinya revolusi industri adalah terjadinya revolusi sains pada abad ke 17 dengan munculnya para ilmuwan seperti Francis Bacon, René Descartes, Galileo Galilei serta adanya pengembangan riset dan penelitian dengan pendirian lembaga riset seperti The Royal Improving Knowledge, The Royal Society of England, dan The French Academy of Science. Revolusi sains yang mulai berkembang pesat diikuti juga dengan terjadinya revolusi industri pertama pada tahun 1784, yang ditandai dengan penemuan mesin uap. Revolusi industri kedua yang dimulai tahun 1870, ditemukan mesin-mesin yang menggunakan daya listrik untuk melangsungkan produksi masal. Revolusi industri ketiga yang terjadi sejak tahun 1969 atau dikatakan juga sebagai era digital, karena menggunakan kekuatan elektronik dan teknologi informasi untuk otomatisasi proses produksi (Tjandrawinata, 2016). Revolusi industri keempat akan segera hadir ke dalam kehidupan kita. Revolusi ini kemajuannya bergerak sangat cepat, oleh karenanya dikatakan sebagai revolusi eksponensial, karena kecepatan perkembangannya berlipatlipat.

\section{Pemikiran Utama Revolusi Saintifik pada Era Eksponensial}

Revolusi sains pada era eksponensial adalah perubahan secara mendasar tatanan hidup masyarakat dunia yang disebabkan oleh perkembangan penemuan sains yang bergerak sangat cepat (Modi, 2017). Prinsip revolusi sains pada era eksponensial adalah mempersatukan beberapa teknologi dari tiga disiplin ilmu independen, yaitu Fisika, Biologi, dan Digital (Tjandrawinata, 2016). Banyaknya penemuan-penemuan sains yang inovatif dan mutakhir dewasa ini telah memberikan "angin segar" bagi masyarakat, karena segala kebutuhan aktivitas hidupnya dapat terlayani dengan mudah dan nyaman oleh produk-produk sains tersebut. Revolusi sains pada era eksponensial telah banyak menghasilkan produk sains yang dapat memanjakan masyarakat dunia karena dapat memanfaatkan internet dengan interkonektivitas yang begitu cepat, sehingga dapat menjelajah dengan mudah dalam dunia maya. Kita dapat merasakan seakan-akan berada pada tempat yang sama dengan orang yang diajak komunikasi, karena melalui kemajuan sains kita dapat berinteraksi, melakukan transaksi, mencari informasi, dan sebagainya.

Kemajuan sains yang berkembang begitu pesat, dapat kita rasakan seperti menembus lorong waktu. Ungkapan tersebut tidaklah berlebihan, karena menurut Tjandrawinata (2016) ruang lingkup otomatisasi dapat ditingkatkan mengikuti hukum moore (suatu pengamatan bahwa jumlah transistor pada suatu sirkuit terpadu meningkat dua kali lipat setiap dua tahun), yang menghasilkan daya komputasi yang semakin besar yang memungkinkan terjadinya otomatisasi dari proses yang sangat kompleks sekalipun. Pada era eksponensial kita dapat melihat berbagai otomatisasi terjadi pada pabrikpabrik yang memperoduksi barang secara masal, data pada setiap bagian suatu organisasi yang masif 
jumlahnya saat ini dikenal sebagai "big data", serta sarana logistik yang terorganisasi dengan begitu baik. Tidak hanya itu, pada era ini telah banyak diciptakan artificial intelligence yang didorong oleh peningkatan eksponensial dalam daya komputasi dan oleh ketersediaan sejumlah besar data. Diprediksikan pada tahun 2030, komputer akan lebih cerdas dari manusia (Modi, 2017).

Tjandrawinata (2016) lebih lanjut mengemukakan bahwa revolusi eksponensial memberikan tawaran dan kesempatan untuk meningkatkan kesejahteraan masyarakat. Teknologi yang dihasilkan sains memungkinkan penjualan prosuk dan jasa secara cepat dan efisien, berfungsi sebagai sekretaris pribadi, pengatur kesehatan, mengelola investasi, mengatur keuangan, memesan makanan, tiket, kendaraan, dan sebagainya. Akan tetapi, sektor bioteknologi kesehatan adalah bidang yang sangat dirasakan dari perkembangan sains di era eksponensial. Hal tersebut bukan tanpa alasan, karena penggunaan bioteknologi dalam industri obat-obatan dan farmasi adalah perkembangan yang paling berpengaruh di dunia teknologi di abad ke-21 ini. Dalam upaya untuk memahami biologi, memberantas penyakit dan menjaga kesehatan dan kekuatan, bioteknologi telah mencapai tingkat yang sangat tinggi dalam usaha menemukan rahasia kehidupan serta memanipulasi kehidupan. Untuk meraih apa yang dijanjikan bioteknologi dalam industri farmasi, alat-alat diperlukan untuk identifikasi struktur molekul, penciptaan molekul aktif dan pengembangan terapi yang novel dan komprehensif seperti immunotherapy, terapi seluler dan organisme dengan sel rekayasa genetika.

Bioteknologi modern menggunakan mikroorganisme hasil rekayasa genetika seperti Escherichia coli, ragi untuk produksi senyawa biologi seperti antibiotika dan insulin sintetis, maupun sel mamalia untuk memproduksi golongan antibodi monoklonal. Akhir-akhir ini, bioteknologi farmasi juga menggunakan hewan transgenik atau tanaman transgenik sebagai medium pembuatan obat. Selain itu, salah satu tekonologi terbaik yang dikembangkan baru-baru ini bernama clustered regularly interspaced shohrt palindromic repeat (CRISPR) atau CRISPR-associated protein (Cas) 9 system, yang telah berkembang pesat hanya dalam waktu yang sangat singkat. Teknologi ini dibuat untuk mengedit genom, ini dapat diterapkan untuk biologi sintetis, skrining genom fungsional, modulasi transkripsi, dan terapi gen. Melihat karakteristiknya, perkembangan bioteknologi lebih mengedepankan pendekatan biologi sintetis (syinthetic biology) sebagai metode penemuannya.

\section{Biologi Sintetis: Penemuan Sains yang Menggemparkan Dunia}

Biologi sintetis (Synthetic biology) dewasa ini mulai "digemari" ilmuwan untuk mengembangkan penelitiannya dalam bidang bioteknologi. Bidang ini dinilai memberi peluang menarik untuk menghasilkan berbagai penemuan penting seperti energi ramah lingkungan, efisiensi proses industri hingga pengembangan obat baru. Tresniawati (2016) dalam sebuah forum Seminar Internasional di IPB, mengemukakan bahwa biologi sintetis merupakan generasi terbaru dari biologi molekuler, menggabungkan beberapa ilmu dasar dan prinsip rancang bangun. Disiplin ilmu yang terkait adalah bioteknologi, biologi evolusi, biologi molekuler, sistem biologi, biofisika, teknik elektro, dan dalam banyak hal yang berkaitan dengan rekayasa genetika, produk atau organisme baru dapat diciptakan dengan cara editing gen. Tujuan dari biologi sintetik adalah menciptakan sistem biologis yang baru, baik pada tingkat molekul, sel, atau organisme baru. Teknologi ini akan menghasilkan organismeorganisme sintetis baru yang sebelumnya tidak pernah ada di dunia ini. Dalam bidang pertanian biologi sintetis menjadi salah satu alternatif untuk produksi pangan yang murah, energi terbarukan, perakitan varietas tanaman tahan cekaman biotik dan abiotik, dan lain-lain.

Boeke (2012) menguatkan bahwa biologi sintetis adalah bidang baru yang berkembang pesat, perpaduan antara ilmu biologi biasa dengan ilmu teknik. Tujuannya untuk menciptakan urutan DNA (Deoxyribonucleic acid) baru yang tidak ada di alam. Hasilnya adalah fungsi dan sistem dalam biologi yang benar-benar baru. Perkembangannya didukung bidang ilmu lain seperti teknologi komputasi, nanoteknologi, dan kemajuan teknik pengujian di laboratorium. Biologi sintetis berbeda dengan rekayasa genitika. Rekayasa genetika menggunakan materi dari sebuah sel, dengan mentrasfer gen ke organisme induk agar memiliki ciri-ciri serupa, sedangkan biologi sintetis berusaha menciptakan fungsi dan sistem biologi baru, bahkan organisme baru. 


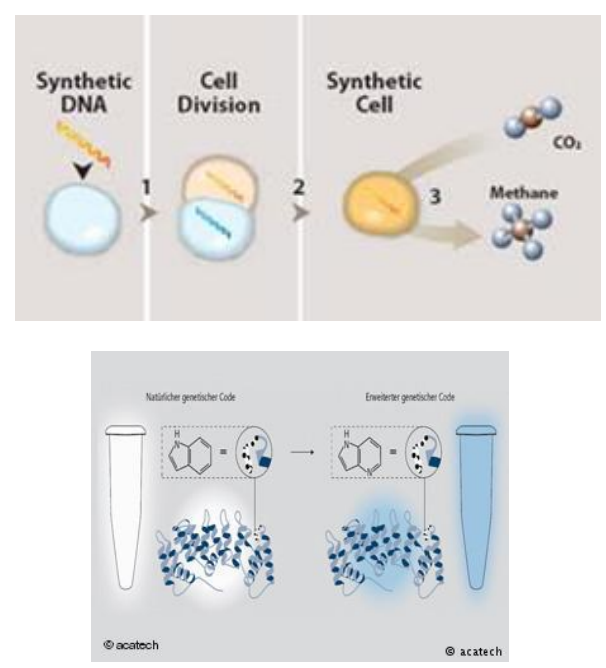

Gambar 1. Metode biologi sintetis

Lebih lanjut Boeke (2012) memaparkan bahwa saat ini sedang dikembangkan proyek untuk memproduksi molekul khusus dalam jumlah yang banyak, seperti biofuel. Dilakukan dengan menciptakan rantai DNA secara sintetis dan memasukkannya ke dalam organisme induk untuk memulai proses dari awal hingga akhir. Analogi hubungan ini seperti software dengan hardware komputer. Ada juga proyek lebih besar, yaitu mendesain gen berbeda dari gen asal. Salah satu yang kami lakukan saat ini adalah membuat kromosom yeast (ragi/sejenis jamur). Boeke juga memberikan penjelasan mengapa proyek yang sedang dikembangkan lebih mengarah terhadap yeast. Yeast banyak digunakan dalam industri fermentasi, termasuk produksi vaksin dan biofuel. Dengan mendesain yeast sesuai kebutuhan tersebut akan dihasilkan jenis vaksin dan biofuel baru yang lebih baik. Yeast adalah jamur bersel satu. la merupakan organisme eukariotik (sel kompleks tertutup membran), sama seperti tanaman, hewan dan manusia. Kemiripan tersebut dapat juga digunakan untuk mempelajari proses sel pada manusia.

Bidang ini dapat digunakan untuk memproduksi berbagai produk baru yang bermanfaat. Dampaknya tentu penciptaan lapangan kerja, serta peningkatan kesejahteraan dan kesehatan masyarakat. Salah satu contohnya adalah penanganan penyakit malaria yang telah membunuh 655.000 orang di dunia pada 2010. Synthetic biology akan berperan penting mengatasinya. Yang terjadi saat ini, obat antimalaria bergantung pada bahan yang mengandung artemisin. Zat kimia tersebut diperoleh dari tanaman bernama Sweet wormwood (Artemisia annua) yang banyak tumbuh di Asia dan Afrika. Sayangnya, kini produksi artemisin terhambat karena habitat tanaman tersebut kian berkurang dan tidak stabil. Akhirnya biayanya pun jadi mahal. Namun synthetic biology mampu menghasilkan pasokan artemisin secara berkelanjutan dengan biaya yang lebih murah. Produk tersebut akan tersedia mulai tahun ini dan didistribusikan ke negara-negara berkembang dengan harga murah. Produsen dan distributor hanya boleh mengambil keuntungan dari produk tersebut dari negaranegara maju, bukan negara berkembang.

Beberapa ilmuwan lainnya yang tergabung dalam J. Craig Venter Institute (JCVI) seperti Ham Smith dan Clyde Hutchinson melakukan sintesis jutaan pasangan basa kromosom bakteri Mycoplasma mycoides, kini mereka berhasil menciptakan organisme hidup dengan genom yang sepenuhnya sintetis pertama di dunia. Penemuan para ilmuwan tersebut merupakan bukti bahwa genom yang didesain di komputer dan dirangkai di laboratorium dapat berfungsi dalam sebuah sel donor, bahkan dapat memperbanyak diri menjadi organisme hidup normal. Ini merupakan pencapaian satu langkah penting dalam sebuah upaya menciptakan kehidupan artifisial. Mereka telah menghasilkan sel hidup pertama yang menggunakan DNA buatan manusia sebagai mesin penggeraknya (BMC, 2017). 


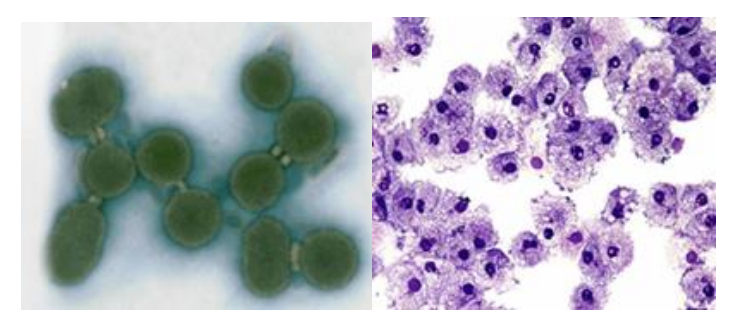

Gambar 2. Wujud sel sintesis pertama yang telah hidup

Namun J. Craig Venter, pionir pemetaan genom, mengatakan proyek timnya tersebut memuluskan jalan menuju tujuan yang jauh lebih sulit: merancang organisme yang dapat bekerja dengan cara yang berbeda daripada bakteri alami untuk berbagai macam kebutuhan. Saat ini dia tengah bekerja sama dengan ExxonMobil untuk mengubah alga menjadi bahan bakar.

\section{Pandangan Filsafat terhadap Revolusi Saintifik pada Era Eksponensial}

Setiap jenis pengetahuan mempunyai ciri-ciri yang spesifik mengenai apa (ontologi), bagaimana (epistemologi), dan untuk apa (aksiologi) pengetahuan tersebut disusun. Ketiga landasan ini saling berkaitan, ontologi ilmu terkait dengan epistemologi ilmu, epistemologi ilmu terkait dengan aksiologi ilmu, dan seterusnya (Suriasumantri, 2009). Begitu pula dengan kajian revolusi sains pada era eksponensial.

\section{Revolusi sains pada era eksponensial ditinjau secara ontology}

Ontologi merupakan salah satu kajian filsafat yang membahas tentang keberadaan sesuatu yang bersifat konkret. Ontologi menyelidiki sifat dasar dari apa yang nyata secara fundamental dan cara yang berbeda dimana entitas (wujud) dari kategori-kategori logis yang berlainan (objek-objek fisik, hal universal, abstraksi) dapat dikatakan ada dalam rangka tradisional. Ontologi dianggap sebagai teori mengenai prinsip-prinsip umum dari hal ada, sedangkan dalam hal pemakaianya akhir-akhir ini ontologi dipandang sebagai teori mengenai apa yang ada. Pada mulanya pandangan ontologi terdapat dua aliran, yaitu aliran monistik dan aliran dualistik (Suriasumantri, 2009).

Lebih lanjut Suriasumantri (2009) memaparkan bahwa Aliran monistik yang dipelopori oleh Christian Wolff (1679-1754) berpendapat bahwa tidak membedakan antara pikiran dan zat, mereka hanya berbeda dalam gejala disebabkan oleh proses yang berlainan namun mempunya substansi yang sama. Dalam hal ini, proses berpikir dianggap sebagai akivitas elektrokimia dari otak. Pendapat ini ditolak oleh kaum yang menganut paham dualistik, yang dipelopori oleh Thomas Hyde (1700). Dalam metafisika penafsiran dualistik membedakan antara zat dan kesadaran (pikiran) yang bagi mereka berbeda sui generis secara substansif. Filsuf yang menganut faham dualistik adalah Rene Descartes (1596-1650), John Locke (1632-1714), dan George Berkeley (1685-1753).

Ketiga ahli filsafat tersebut berpendapat bahwa apa yang ditangkap oleh pikiran, termasuk penginderaan dari segenap pengalaman manusia, adalah bersifat mental. Bagi Descartes, yang bersifat nyata adalah pikiran sebab dengan pikiranlah maka sesuatu itu lantas ada. Descartes terkenal dengan adagium yang dikemukakannya: "aku berpikir maka aku ada (latin: cogito ergo sum)". Bagi Descartes kebenaran yang dapat membentuk pengetahuan baru haruslah berpangkal pada sesuatu kepastiannya benar-benar tidak dapat disangsikan. Oleh sebab itu untuk memastikan sesuatu itu benar, terlebih dahulu kebenaran itu harus disangsikan/ diragukan kebenarannya. Apabila kebenaran sanggup bertahan dari keragu-raguan, maka kebenaran itu merupakan kebenaran yang pasti. Manusia harus menjadi pangkal pemikiran rasional untuk mencapai kebenaran yang pasti (Suriasumantri, 2009).

Merunut dari pemikiran Descartes, terjadinya revolusi sains disebabkan karena perkembangan pikiran manusia, dan itu nyata terjadi wujudnya. Termasuk yang terjadi pada era eksponensial saat ini, pada mulanya banyak orang menyangsikan tentang rekayasa genetika, biologi sintetis dan produk bioteknologi lainnya, bahkan produk sains lainnya di era eksponensial ini, apakah benar-benar terjadi? 
Buktinya saat ini, semua yang disangsikan itu dapat kita rasakan, bukan hanya gejalanya, melainkan kita telah menggunakan sebagian produknya. Bahkan kita tidak tau apa yang akan terjadi di depan nantinya? Jika kita memikirkan tentang kemajuan penemuan-penemuan sains, bahkan hingga terjadi revolusi sains, seakan-akan ilmu dan pemikiran manusia tidak ada batasnya. Menanggapi pernyata tersebut Suriasumantri (2009) menjawab dengan sederhana, bahwa sains memulai penjelajahannya pada pengalaman manusia dan berhenti di batas pengalaman manusia. Fungsi sains dalam kehidupan manusia, yaitu sebagai alat bantu manusia dalam menanggulangi masalah-masalah yang dihadapinya sehari-hari.

\section{Revolusi sains pada era eksponensial ditinjau secara epistemologi}

Epistemologi adalah cabang filsafat yang membahas cara mendapatkan pengetahuan, meliputi sumber, struktur, metode, dan validitas pengetahuan. Dalam sejarah perkembangannya konsep epistemologi telah banyak digunakan oleh para filsuf untuk mendapatkan pengetahuan dengan berbagai cara. Namun pada akhirnya ditemukanlah cara yang terbaik untuk memperoleh pengetahuan hingga saat ini yaitu dengan metode ilmiah, yang menggabungkan cara berpikir deduktif dan induktif (Suriasumantri, 2009).

Galileo (1564-1642) dan Newton (1642-1727) merupakan pionir yang mempergunakan gabungan berpikir deduktif dan induktif ini dalam penyeledikan ilmiah mereka. Penelitian Charles Darwin (1809-1882) yang membuahkan teori evolusinya juga menggunakan metode ilmiah. Dengan berkembangnya metode ilmiah dan diterimanya metode ini sebagai paradigma oleh masyarakat sains, maka sejarah kemanusiaan menyaksikan perkembangan pengetahuan yang sangat cepat. Dirintis oleh Copernicus (1473-1543), Kepler (1571-1630), Galileo (1564-1642) dan Newton (1642-1727) sains mendapatkan momentumnya pada abad ketujuh belas hingga saat ini tinggal landas (Suriasumantri (2009).

Perkembangan sains dari masa ke masa yang dimulai dari abad ketujuh belas hingga saat ini masih menganut metode ilmiah sebagai cara berpikir untuk menemukan pengetahuan. Begitu pula dengan yang dilakukan oleh para ilmuwan sains di era eksponensial, metode ilmiah masih dianggap sebagai cara yang terbaik untuk membuktikan penemuan-penemuannya. Dengan menggunakan metode ilmiah, kita dapat mengetahui kebenaran dari penemuan sains tersebut.

\section{Revolusi sains pada era eksponensial ditinjau secara aksiologi}

Penemuan-penemuan sains yang terus berkembang rupanya menjadi paradoks bagi masyarakat dunia. Pada satu sisi sains membawa kemajuan dan kesejahteraan manusia, namun pada posisi yang berbeda sains menjadi malapetaka bagi kehidupan manusia itu sendiri. Artinya, dalam menggunakan sains, masyarakat harus bijaksana dan tidak boleh hanya menggunakan secara praktis. Demikian pula yang terjadi pada revolusi sains di era eksponensial, banyak perkembangan sains yang telah mengubah tatanan hidup manusia secara fundamental. Jika perkembangan tersebut tidak disikapi secara bijaksana, maka sains akan membahayakan bagi manusia itu sendiri. Oleh karenanya, masyarakat yang menggunakan sains harus memperhatikan etika dan moral, atau dalam filsafat harus ditinjau dari segi aksiologi.

Suriasumantri (2009) memaparkan dalam bukunya "Filsafat ilmu sebuah pengantar populer" bahwa saat ini sudah merupakan eranya manusia yang menyesuaikan teknologi. Teknologi tidak lagi berfungsi sebagai sarana yang memberikan kemudahan bagi kehidupan manusia melainkan berada untuk tujuan eksistensinya sendiri. Jadi, sains bukan saja menimbulkan gejala dehumanisasi namun bahkan kemungkinan mengubah hakikat kemanusiaan itu sendiri. Sebenarnya sejak awal pertumbuhannya ilmu sudah terkait dengan masalah-masalah moral namun dalam perspektif yang berbeda. Contohnya Copernicus yang mengajukan teorinya tentang kesemestaan alam dan menemukan bahwa "bumi yang berputar mengelilingi matahari" dianggap menentang terhadap yang diajarkan oleh agama.

Dalam konteks ini, jelas bahwa sains tidak bisa terbebas dari nilai. Penciptaan sains bersifat individual, namun komunikasi dan penggunaannya bersifat sosial. Peranan individu inilah yang 
menonjol dalam kemajuan sains dimana penemuan seorang seperti Newton dan Edison dapat mengubah wajah peradaban, karena kreativitas individu yang didukung oleh sistem komunikasi sosial yang bersifat terbuka menjadi proses pengembangan sains yang berjalan sangat efektif (Suriasumantri, 2009).

\section{Persepsi Masyarakat dalam Menyikapi Revolusi Saintifik pada Era Eksponensial}

Masyarakat dunia menilai perkembangan-perkembangan penemuan sains pada era eksponensial sarat dengan kontroversial, terutama jika ditinjau dari segi moral dan etika. Banyak orang mengkhawatirkan dan bahkan Tjandrawinata (2016) memaparkan bahwa kemajuan sains di era ini menyebabkan terjadinya perubahana besar pada fitrah manusia dan berujung pada pertanyaan filosofis mengenai eksistensi dan nilai manusia secara hakiki. Anggapan tersebut bukan tanpa alasan, mengingat pesatnya kemajuan sains terutama dalam bidang bioteknologi, yang pada era eksponensial mengedepankan penemuan-penemuan di bidang biologi sintetis.

Penelitian biologi sintetis untuk menciptakan organisme hidup buatan di laboratorium, sesuai desain yang diharapkan, hingga kini masih memicu kontroversi. Heller dan Setiawan (2011) menjelaskan bahwa Para periset di bidang biologi sintetis terus berupaya menciptakan mikro organisme artifisial dari semacam sukucadang molekuler, yang memiliki sifat dan perilaku khas, misalnya dapat memasok energi atau menjadi bahan dasar obat-obatan jenis baru. Target yang hendak dicapai oleh para periset di bidang ini adalah menciptakan sistem biologis buatan, berupa sukucadang sel-sel sederhana, yang dapat didesain menjadi organisme hidup yang memiliki sifat istimewa. Para penentang risetnya mengkhawatirkan, mikro organisme artifisial baru itu dapat merusak keseimbangan ekosistem dengan dampak merugikan. Sementara para pendukung teknologi biologi sintetis mengharapkan revolusi di bidang kedokteran, penyediaan energi dan banyak hal lainnya.

Sven Panke adalah salah seorang ilmuwan terkemuka di bidang biologi molekuler dan rekayasa genetika yang menekuni riset biologi sintetis ini. la melakukan penelitian sifat serta mekanisme fungsi sel, gen, protein dan enzym. Sejak tahun 2009, Panke pakar bioteknologi dari Braunschweig Jerman, bekerja sebagai pimpinan laboratorium proses biologi di departemen untuk biosytem di Basel, Swiss. Panke mengungkapkan visinya adalah "sistem biologis, sel-sel yang sederhana, sukucadang yang dimengerti dengan baik, yang gampang dibangun menjadi sel-sel yang berguna, dan sistem baru itu memproduksi apa yang saya inginkan, bukan yang lainya" (Heller dan Setiawan, 2011).

Jika Panke dan tim penelitinya berhasil menemukan sistem biologis itu, di masa depan sel-sel atau bakteri dengan sifat-sifat yang diinginkan dapat didesain di laboratorium. Informasi genetikanya dapat diprogram menggunakan komputer. Komposisinya dibangun dari sukucadang yang sudah terstandarisasi, yang diproduksi secara sintetis. Panke mengatakan, secara teoritis hampir semua unsur aktif dapat dibuat dengan sistem biologis tersebut. Sven Panke menyadari ia bekerja di bidang keilmuan yang memicu kontroversi. Alasannya adalah ketakutan akan ancaman bahaya berupa bencana biologi yang belum dikenal sebelumnya.

Walaupun terdapat potensi luar biasa dalam cabang keilmuan biologi sintetis, Panke juga menyadari adanya penolakan secara instinktif terhadap bidang yang belum lama muncul itu. Bagi banyak orang, menciptakan kehidupan dari sukucadang biologi sama sekali tidak dapat diterima. Para ilmuwan tidak dapat mengabaikan begitu saja ketakutan publik ini. Karena itulah transparansi amat penting. Informasi harus disebarkan secara terbuka. Sama terbukanya dengan mengakui adanya potensi keuntungan besar ýang dapat mengubah kehidupan secara revolusioner, dan kemungkinan dampak negatifnya berupa bencana ekositem.

Saat ini di Eropa khususnya di Jerman, dilancarkan perdebatan secara intensif, berkaitan dengan tema biologi sintetis. Karena itulah pakar biologi sintetis itu terus berusaha agar temanya dibahas secara hati-hati. Untuk itu dalam berbagai kongres, seminar dan lokakarya di berbagai negara Eropa, Panke selalu mengimbau rekan-rekan sejabatnya agar sedapat mungkin bersikap transparan. Juga mengupayakan dibukanya dialog dengan publik, sebagai upaya melunasi utang informasi yang kurang kepada publik (Heller dan Setiawan, 2011).

Kontroversi tidak hanya terjadi di Eropa saja, BMC (2017) memaparkan bahwa di Amerika 
Presiden Barack Obama langsung menunjuk komisi presidensial untuk studi isu bioetika yang dibentuknya tahun lalu agar langsung mempelajari temuan tersebut. Komisi itu akan mempertimbangkan potensi medis, lingkungan, keamanan dan manfaat lain risert tersebut, begitu pula adanya potensi risiko kesehatan, keamanan, atau risiko lainnya. Obama juga meminta komisi tersebut membuat rekomendasi tentang langkah yang harus diambil pemerintah. Untuk menjamin bahwa Amerika memperoleh manfaat dari bidang ilmu yang tengah berkembang ini sambil mengidentifikasi batasan etika yang diperlukan dan meminimalisasi risiko yang teridentifikasi.

Menurut Dwijayanti (2016), seorang mahasiswa doktoral Synbio di Imperial College London, Inggris mengemukakan anggapan masyarakat dunia bahwa sebagai ilmu yang terkait rekayasa genetik atau sel, muncul tudingan bahwa synbio sebagai 'playing God.' Itu sebabnya ilmu ini sulit berkembang, khususnya di Indonesia. Namun ia menepis asumsi tersebut, karena menurutnya, kurangnya perkembangan synbio (syinthetic biology) khususnya di Indonesia karena ilmu tersebut termasuk ilmu baru. Indonesia masih sedang belajar dan mencari potensi pengembangan ilmu ini. Jadi masih butuh waktu untuk bisa berkembang di Indonesia.

Dengan demikian, untuk menyikapi revolusi sains di era eksponensial khususnya bidang bioteknologi, masyarakat harus siap menyambut perubahan paradigma dalam sains dan berpikir cerdas untuk menyikapi secara bijaksana penggunaan produk-produk sains yang mutakhir. Peran pemerintah sangat dibutuhkan dalam hal ini, sebagai controling system yang mengendalikan penemuan-penemuan sains yang terus berkembang dan didalam menggunakan produk sains itu sendiri. Pemerintah dan masyarakat harus bahuh membahu mensukseskan revolusi sains di era eksponensial ini untuk visi utama, yaitu meningkatkan kesejahteraan masyarakat dunia.

\section{PENUTUP}

Saat ini, menjelajahi dunia bukan lagi hal yang mustahil untuk dilakukan, karena berkat kemajuan sains kita dapat mengakses dengan mudah segala informasi di dunia ini. Bahkan lebih dari itu, kita dapat berinteraksi dengan orang yang berbeda negara hanya dengan sentuhan jari pada teknologi canggih, seolah-olah kita memasuki lorong waktu. Itulah revolusi sains yang telah dipersembahkan kepada masyarakat dunia, teruatama di era eksponensial. Tatanan kehidupan masyarakat menjadi bergesar dari yang semula beraktivitas seluruhnya mengandalkan fisik tubuh manusia menjadi mengandalkan pada kecanggihan teknologi. Perubahan inilah yang dikhawatirkan oleh para filsuf sains, manusia akan kehilangan eksistensinya secara hakiki karena dapat menyebabkan terjadinya perubahan besar secara filosofis pada hakikat dan fitrah eksistensi manusia dalam hidupnya.

Kemajuan sains rupanya menjadi paradoks bagi kehidupan manusia, bagaikan dua belah mata pisau. Pada satu sisi, kemajuan sains sangat membantu kesejahteraan manusia, di sisi lain memberikan dampak negatif terhadap manusia itu sendiri. Oleh karenanya, perkembangan sains harus disikapi secara bijaksana dan dikaji secara filsafat, terutama dari nilai-nilai etika. Secara aksiologi revolusi sains harus dikaji secara mendalam agar perkembangan sains tersebut dapat diterima oleh masyarakat secara menyeluruh. Hal yang tidak kalah pentingnya adalah pemerintah harus berperan sebagai controling system dalam mengendalikan kebijakan-kebijakan penciptaan dan penggunaan produk sains, agar masyarakat tidak hanya menggunakan sains secara praktis. Tentu saja dalam praktiknya, masyarakat harus dapat mengadaptasikan kemajuan sains dengan kondisi dan budaya yang berlaku pada lingkungannya.

\section{DAFTAR PUSTAKA}

Biologi Media Centre (2017). Sel hidup sintetis pertama berhasil dibuat [online]. Tersedia: http://biologimediacentre.com/sel-hidup-sintetis-pertama-berhasil-dibuat/. [5 April 2017]. 
Boeke, J.D. (2012). Teknologi: Mengenal Biologi Sintetis [online]. Tersedia: http://www.solopos.com/2012/03/26/teknologi-mengenal-biologi-sintetis-173355. [5 April 2017].

Dwijayanti, A. (2016). IImu synbio saat ini berkembang cukup pesat di negara-negara maju dan baru berkembang kurang dari dua dekade [Online]. Tersedia: https://bandung.merdeka.com/profil/kembangkan-ilmu-biologi-sintetik-gadis-ini-terbang-keinggris-160111x.html. [5 April 2017].

Firman, H. (2016). Scientific Revolution. Bahan Kuliah Filsafat IImu Program Doktoral. Universitas Pendidikan Indonesia: tidak diterbitkan .

Heller, L. \& Setiawan, A. (2011). Biologi Sintetis Masih Diperdebatkan [Online]. Tersedia: http://www.dw.com/id/biologi-sintetis-masih-diperdebatkan/a-15124761. [5 April 2017].

Kuhn, T. (1962). The Strcuture of Scientific Revolutions. Chicago: The University of Chicago Press.

Modi, S. (2017). Revolusi Industri IV, Exponential Era [Online]. Tersedia: https://kissparry.wordpress.com/2017/04/07/revolusi-industri-ke-4-exponential-era/. [21 April 2014].

Suriasumantri, J.S. (2009). Filsafat Ilmu: Sebuah Pengantar Popular. Jakarta: Pustaka Sinar Harapan.

Tjandrawinata, R.R. (2016). Industri 4.0: revolusi industri abad ini dan pengaruhnya pada bidang kesehatan dan bioteknologi. Jakarta: Working Paper from Dexa Medica Group.

Tresniawati, C. (2016). Mengenal Tren Penelitian Biologi Sintetik di Dunia Internasioal [Online]. Tersedia: $\quad$ http://balittri.litbang.pertanian.go.id/index.php/berita/berita-lain/309-mengenal-trenpenelitian-biologi-sintetik-di-dunia-internasional. [5 April 2017]. 